\title{
Shewanella loihica sp. nov., isolated from iron-rich microbial mats in the Pacific Ocean
}

\author{
Haichun Gao, ${ }^{1,2,3}$ Anna Obraztova, ${ }^{4}$ Nathan Stewart, ${ }^{2}$ Radu Popa, ${ }^{5}$ \\ James K. Fredrickson, ${ }^{6}$ James M. Tiedje, ${ }^{2}$ Kenneth H. Nealson ${ }^{4}$ \\ and Jizhong Zhou ${ }^{1,3}$ \\ ${ }^{1}$ Environmental Sciences Division, Oak Ridge National Laboratory, Oak Ridge, TN, USA \\ ${ }^{2}$ Center for Microbial Ecology, Michigan State University, East Lansing, MI, USA \\ ${ }^{3}$ Stephenson Research and Technology Center, Institute for Environmental Genomics, \\ University of Oklahoma, 101 David L. Boren Boulevard, Norman, OK 73019, USA \\ ${ }^{4}$ Department of Biological Sciences, University of Southern California, Los Angeles, CA, USA \\ ${ }^{5}$ Department of Biology, Portland State University, Portland, OR, USA \\ ${ }^{6}$ Pacific Northwest National Laboratory, Richland, WA, USA
}

Correspondence Jizhong Zhou jzhou@ou.edu
The genus Shewanella consists of rod-shaped, Gramnegative, facultatively anaerobic, readily cultivated gammaproteobacteria (Gauthier et al., 1995; MacDonell \& Colwell, 1985; Venkateswaran et al., 1999). While many Shewanella strains remain uncharacterized, there are 32 recognized Shewanella species: the latter were isolated from a variety of sources, primarily aquatic environments and sediments (Bowman et al., 1997; Bozal et al., 2002; Brettar et al., 2002; Coyne et al., 1989; Ivanova et al., 2001, 2003a, b, 2004a, b, c; Leonardo et al., 1999; Makemson et al., 1997; Nogi et al., 1998; Nozue et al., 1992; Satomi et al., 2003, 2006; Skerratt et al., 2002; Toffin et al., 2004; Venkateswaran et al., 1998, 1999; Xu et al., 2005; Yoon et al., 2004a, b; Zhao et al., 2005,

The GenBank/EMBL/DDBJ accession number for the 16S rRNA gene sequence of strain $\mathrm{PV}-4^{\top}$ is $\mathrm{DQ} 286387$.

The fatty acid compositions of strain $\mathrm{PV}-4^{\top}$ and $S$. aquimarina JCM $12193^{\top}$ are detailed in a supplementary table in IJSEM Online.
2006; Ziemke et al., 1998). The bacteria of this genus have attracted great attention because of their diverse respiratory capacities, illustrated by their ability to utilize a wide range of terminal electron acceptors, including oxygen, nitrate, metals and sulfur compounds (Kostka et al., 1996; Myers \& Nealson, 1988; Venkateswaran et al., 1999; http://www. shewanella.org). Some Shewanella strains are also able to degrade pollutants such as chlorinated solvents (Petrovskis et al., 1994), petroleum (Semple \& Westlake, 1987) and RDX (1,3,5-trinitroperhydro-1,3,5-triazine) (Zhao et al., 2004), some can produce polyunsaturated fatty acids (Bowman et al., 1997; Russell \& Nichols, 1999; Satomi et al., 2003) and some are able to grow under extreme conditions (Bozal et al., 2002; Kato et al., 1998; Nogi et al., 1998; Stapleton et al., 2005).

In a previous study, several Shewanella strains were isolated from marine-sediment samples at a variety of locations in the Pacific Ocean (Stapleton et al., 2005). Among these 
strains was Shewanella sp. PV-4 ${ }^{\mathrm{T}}$, which was isolated from iron-rich microbial mats at the active, deep-sea, hydrothermal Naha Vent (1325 m below sea level) located on the South Rift of Loihi Seamount, Hawaii (http://www.soest. hawaii.edu/GG/HCV/loihivents.html). Although the draft genome sequence of strain PV- $4^{\mathrm{T}}$ was released recently (by the Joint Genome Institute; see http://www.jgi.doe.gov) and its morphology, metal-reduction capacity and biomineralization ability have been explored, its taxonomic status has remained undefined (Roh et al., 2006). The objective of the present study was to establish the taxonomic position of strain PV-4 $4^{\mathrm{T}}$, by using a combination of polyphasic taxonomic data.

Standard protocols, including those for determining the Gram reaction, catalase and oxidase activities and spore formation (Smibert \& Krieg, 1994), were employed to establish the physiological and biochemical properties of strain PV$4^{\mathrm{T}}$. Enzymic hydrolysis of various substrates, including casein, starch, gelatin, Tweens 20, 40 and 80 and DNA, and a determination of the production of $\mathrm{H}_{2} \mathrm{~S}$ from thiosulfate were conducted, using marine broth 2216, as described elsewhere (Smibert \& Krieg, 1994; Bowman et al., 1997). Other phenotypic and enzymic characterizations of strain PV-4 ${ }^{\mathrm{T}}$ were conducted using API 20E, API ID 32A and API ZYM test kits (bioMérieux) and Biolog PM plates (Biolog), according to the instructions of the manufacturers. The $\mathrm{pH}$ and temperature ranges for growth were determined on marine 2216 medium (Difco). The requirement for $\mathrm{Na}^{+}$ ions was studied using a medium described elsewhere (Ivanova et al., 2003b). Salt-tolerance tests were performed on marine 2216 medium with $\mathrm{NaCl}$ concentrations of $0 \cdot 5-8 \cdot 0 \%(\mathrm{w} / \mathrm{v})$. The reduction of electron acceptors was assessed using M1 defined medium supplemented with lactate $(10 \mathrm{mM})$ as the electron donor and one of the electron acceptors as described previously (Roh et al., 2006). The reduction of electron acceptors with $\mathrm{N}$-acetylglucosamine $(10 \mathrm{mM})$ as the electron donor was examined in this study by using the same procedure. The electron acceptors tested include $\mathrm{MnO}_{2}(5 \mathrm{mM})$, ferric citrate $(20 \mathrm{mM})$, ferric EDTA $(10 \mathrm{mM})$, akaganeite $(\beta-\mathrm{FeOOH} ; 70 \mathrm{mM})$, cobalt [Co(III)] EDTA $(1.5 \mathrm{mM})$, potassium chromate [Cr(VI); $0.5 \mathrm{mM}]$, uranyl $[\mathrm{U}(\mathrm{VI})]$ carbonate $(5 \mathrm{mM})$, hydrous ferric oxides (40 mM), DMSO (10 mM), sodium nitrate (3 mM), sodium nitrite $(0.5 \mathrm{mM})$, sulfur $(40 \mathrm{mM})$, sodium thiosulfate $(5 \mathrm{mM})$, sodium sulfate $(5 \mathrm{mM})$, sodium sulfite $(5 \mathrm{mM})$ and trimethylamine $\mathrm{N}$-oxide $(10 \mathrm{mM})$.

The morphological, physiological and biochemical characteristics of strain PV $-4^{\mathrm{T}}$ are given in Table 1. Consistent with species of the genus Shewanella, strain PV $-4^{\mathrm{T}}$ is a rod-shaped bacterium with a single polar flagellum (Roh et al., 2006). Biomass of strain PV-4 ${ }^{\mathrm{T}}$ exhibited an orangey colour under aerobic conditions. In general, the physiological and biochemical characteristics of strain $\mathrm{PV}-4^{\mathrm{T}}$ are typical of species of the genus Shewanella (Venkateswaran et al., 1999). However, strain PV-4 ${ }^{\mathrm{T}}$ exhibits some unique features. Strain PV $-4^{\mathrm{T}}$ was found to be psychrotolerant and
Table 1. Characteristics that differentiate strain $P V-4^{\top}$ from phylogenetically related species

Taxa: 1, strain PV-4 $4^{\mathrm{T}} ; 2$, Shewanella affinis; 3, S. aquimarina; 4, Shewanella colwelliana; 5, S. marisflavi; 6, Shewanella waksmanii. Data are from this study, Ivanova et al. (2003b, 2004b), Weiner et al. (1988) and Yoon et al. (2004b). Cells of all species are straight, rod-shaped, Gram-negative and polarly flagellated. All species are oxidase-, catalase- and gelatinase-positive and negative for the utilization of sucrose, D-fructose and glycerol. Symbols: + , positive; -, negative; $\mathrm{V}$, variable (depending on the strain); ND, no data available.

\begin{tabular}{|lcccccc|}
\hline Characteristic & $\mathbf{1}$ & $\mathbf{2}$ & $\mathbf{3}$ & $\mathbf{4}$ & $\mathbf{5}$ & $\mathbf{6}$ \\
\hline DNA G+C content (mol\%) & 54 & 45 & 54 & 46 & 51 & 43 \\
Growth in/at: & & & & & & \\
$4{ }^{\circ} \mathrm{C}$ & + & - & - & + & + & + \\
$42{ }^{\circ} \mathrm{C}$ & + & - & + & - & + & - \\
$0 \% \mathrm{NaCl}$ & - & - & - & - & + & - \\
$8 \% \mathrm{NaCl}$ & - & $\mathrm{V}$ & + & - & + & - \\
$\mathrm{pH} 4 \cdot 5$ & + & $\mathrm{ND}$ & - & $\mathrm{ND}$ & - & - \\
pH 10 & + & $\mathrm{ND}$ & - & $\mathrm{ND}$ & - & + \\
Reduction of nitrate to nitrite & - & + & + & + & + & + \\
$\mathrm{H}{ }_{2} \mathrm{~S}$ from thiosulfate & - & + & + & $\mathrm{ND}$ & + & $\mathrm{ND}$ \\
$\alpha$-Glucosidase & + & $\mathrm{ND}$ & - & $\mathrm{ND}$ & - & $\mathrm{ND}$ \\
$\beta$-Glucosidase & + & $\mathrm{ND}$ & - & $\mathrm{ND}$ & - & $\mathrm{ND}$ \\
Utilization of: & & & & & & \\
Fumarate & + & - & - & + & - & - \\
Galactose & + & - & + & - & - & - \\
Glucose & + & + & - & $\mathrm{ND}$ & + & + \\
Citrate & + & + & - & - & - & - \\
Lactate & + & + & + & - & + & - \\
Malate & + & $\mathrm{ND}$ & + & - & + & $\mathrm{ND}$ \\
Maltose & + & $\mathrm{ND}$ & + & - & + & $\mathrm{ND}$ \\
$\quad$-Acetylglucosamine & + & $\mathrm{ND}$ & + & $\mathrm{ND}$ & + & - \\
Succinate & + & - & + & - & + & - \\
& & & & & & \\
\hline
\end{tabular}

able to grow over unusually wide ranges of temperature $\left(0-42{ }^{\circ} \mathrm{C}\right), \mathrm{pH}(4 \cdot 5-10)$ and salt $(0 \cdot 5-5 \%)$. The optimal temperature, $\mathrm{pH}$ and salt concentration for growth were $18^{\circ} \mathrm{C}, \mathrm{pH}$ 6-8 and $2 \%$, respectively. In contrast to most Shewanella species, strain PV $-4^{\mathrm{T}}$ was able to utilize alanine. However, unlike most Shewanella species, $\mathrm{PV}-4^{\mathrm{T}}$ was unable to utilize acetate, propionate or Tween 40. Unlike some Shewanella species, strain PV $-4^{\mathrm{T}}$ does not show any growth with nitrate, nitrite, thiosulfate, sulfur, sulfate, sulfite or DMSO as the electron acceptor and lactate as the electron donor.

For quantitative analysis of cellular fatty acid compositions, cell mass of strains $\mathrm{PV}-4^{\mathrm{T}}$ and Shewanella aquimarina JCM $12193^{\mathrm{T}}$ was obtained from Luria-Bertani agar plates after cultivation for 2 days at room temperature and fatty acid profiles were determined using the Sherlock System (MIDI) at the University of Florida, Gainesville, FL, USA (http://plantpath.ifas.ufl.edu/fame/). Isoprenoid quinones were extracted and analysed as described by 
Ivanova et al. (2003b). The cellular fatty acids observed in $\mathrm{PV}-4^{\mathrm{T}}$ were similar to those of S. aquimarina JCM $12193^{\mathrm{T}}$, ranging from $\mathrm{C}_{12}$ to $\mathrm{C}_{18}$, and included saturated, monoenoic, straight-chain and iso-branched components (see Supplementary Table S1, available in IJSEM Online). Major fatty acids included $\mathrm{C}_{\mathrm{i} 13: 0}, \mathrm{C}_{\mathrm{i} 13: 0} 3-\mathrm{OH}, \mathrm{C}_{\mathrm{i15}: 0}, \mathrm{C}_{16: 0}$, $\mathrm{C}_{\mathrm{i} 17: 0}, \mathrm{C}_{17: 1} \omega 8, \mathrm{C}_{18: 1} \omega 7$. Strain PV-4 ${ }^{\mathrm{T}}$ contained ubiquinones, consisting mainly of Q-7 and Q-8, and menaquinone MK-7. However, methylmenaquinones were not detected.

The DNA G $+\mathrm{C}$ content of strain PV $-4^{\mathrm{T}}$ is $53.8 \mathrm{~mol} \%$ and the genome size is $4.5 \mathrm{Mbp}$ (on the basis of the draft genome sequence). The almost-complete $16 \mathrm{~S}$ rRNA gene sequence for strain PV $-4^{\mathrm{T}}$ was also amplified and sequenced as described elsewhere (Roh et al., 2006). Other Shewanella 16S rRNA gene sequences were obtained from GenBank or the Ribosomal Database Project (http://rdp.cme.msu.edu/ index.jsp). Sequence alignment and phylogenetic relationships were established with the neighbour-joining DNA distance program in the MEGA3 package (Kumar et al., 2004) (Fig. 1). The phylogenetic analysis clearly showed that strain PV $-4^{\mathrm{T}}$ belonged to the genus Shewanella. The 16S rRNA gene sequence of strain PV-4 ${ }^{\mathrm{T}}$ showed $99 \cdot 6$ and $97.5 \%$ similarity, respectively, to those of the type strains of its nearest phylogenetic relatives, S. aquimarina and Shewanella marisflavi. The levels of 16S rRNA gene sequence similarity between strain $\mathrm{PV}-4^{\mathrm{T}}$ and the type strains of other recognized Shewanella species were below 96.5\%. As reported by Stackebrandt \& Goebel (1994), species definition in general requires $16 \mathrm{~S}$ rRNA sequence similarities greater than $97 \cdot 5 \%$. Thus, strain PV $-4^{\mathrm{T}}$ could be a strain belonging to the species $S$. aquimarina or $S$. marisflavi.

To determine whether PV $-4^{\mathrm{T}}$ is a strain within S. aquimarina or S. marisflavi, DNA-DNA hybridizations were performed between PV-4 ${ }^{\mathrm{T}}$ and S. aquimarina JCM $12193^{\mathrm{T}}$ and between PV $-4^{\mathrm{T}}$ and S. marisflavi JCM $12192^{\mathrm{T}}$. Genomic DNA was extracted from these two strains for DNADNA hybridization, as described previously (Zhou et al., 1996). DNA hybridizations were carried out using the microplate procedure, as described elsewhere (Goris et al., 1998). Strain PV $-4^{\mathrm{T}}$ displayed mean DNA-DNA relatedness values of $50 \cdot 5$ and $8 \cdot 5 \%$ with respect to $S$. aquimarina JCM $12193^{\mathrm{T}}$ and S. marisflavi JCM $12192^{\mathrm{T}}$, respectively. As these values are below the $70 \%$ similarity threshold specified by Wayne et al. (1987), strain PV-4 ${ }^{\mathrm{T}}$ should be considered as representing a different species within the genus Shewanella.

In summary, on the basis of phenotypic, physiological, chemotaxonomic, phylogenetic and genetic data, we propose that strain $\mathrm{PV}-4^{\mathrm{T}}$ represents a novel species of

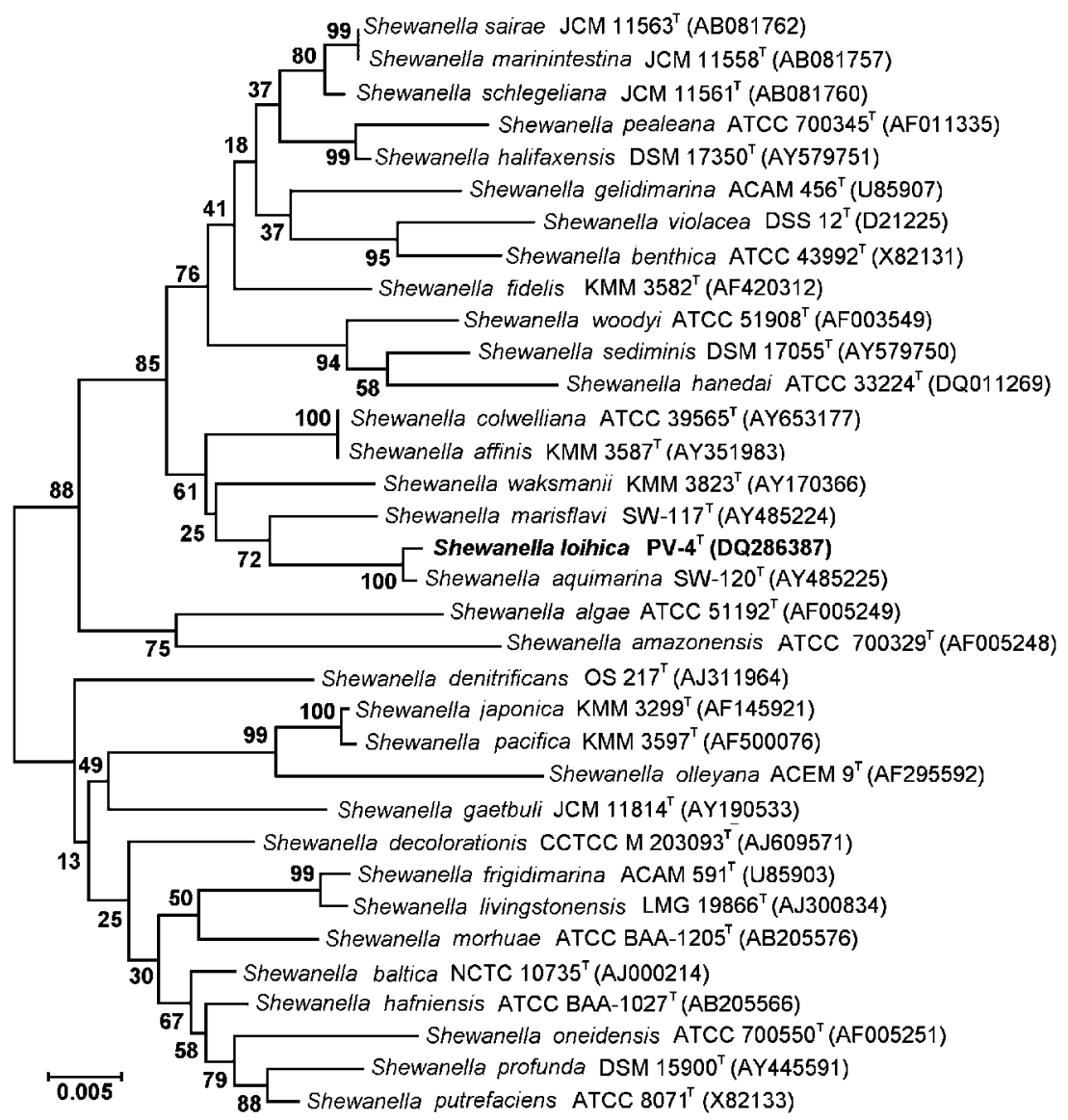

Fig. 1. Phylogenetic tree, based on $16 \mathrm{~S}$ rRNA gene sequences, showing the taxonomic position of strain $\mathrm{PV}-4^{\mathrm{T}}$ within the genus Shewanella. The tree was created using the neighbour-joining method included in MEGA3. Numbers at nodes indicate bootstrap percentages. Bar, 5 nucleotide differences per 1000 positions. 
Shewanella, for which we propose the name Shewanella loihica sp. nov.

\section{Description of Shewanella loihica sp. nov.}

Shewanella loihica (lo.i.hi'ca. N.L. fem. adj. loihica of Loihi Seamount, where the type strain was isolated).

Gram-negative, non-spore-forming, straight rod with a mean length of $1.8 \mu \mathrm{m}$ and a mean width of $0.7 \mu \mathrm{m}$. Motile by means of a single polar flagellum. Facultative psychrotolerant anaerobe. Colonies are smooth, glistening, circular, flat to slightly raised, orange in colour and $2 \cdot 0-4 \cdot 0 \mathrm{~mm}$ in diameter after 2 days incubation in air at room temperature on Luria-Bertani agar plates. Grows at temperatures ranging from 0 to $42^{\circ} \mathrm{C}$, with $18{ }^{\circ} \mathrm{C}$ as the optimum. Does not grow at temperatures above $43{ }^{\circ} \mathrm{C} . \mathrm{pH}$ range for growth is $4 \cdot 5-10 \cdot 0$ (optimum, $\mathrm{pH} 6 \cdot 0-8 \cdot 0$ ). $\mathrm{Na}^{+}$is required for growth. Grows at $0 \cdot 5-5 \% \mathrm{NaCl}$, with an optimum at $2 \%$ $\mathrm{NaCl}$; does not grow in the presence of more than $6 \% \mathrm{NaCl}$. Grows under anaerobic conditions. With lactate as the substrate, fumarate, $\mathrm{MnO}_{2}$, ferric citrate, akaganeite, cobalt [Co(III)] EDTA, potassium chromate, uranyl carbonate, hydrous ferric oxides and trimethylamine $\mathrm{N}$-oxide are reduced, but ferric EDTA, nitrate, nitrite, thiosulfate, sulfur, sulfate, sulfite and DMSO are not. Susceptible to chloramphenicol, erythromycin, gentamicin, kanamycin, rifampicin and tetracycline. Slightly susceptible to spectinomycin and streptomycin. Resistant to ampicillin. Casein, gelatin, Tween 20 and Tween 80 are hydrolysed. Positive for oxidase, ornithine decarboxylase, urease, citrate utilization, $p$-phenylalanine deaminase, arginine dihydrolase, $\alpha$-glucosidase, $\quad \beta$-glucosidase, $N$-acetyl- $\beta$-glucosaminidase and malonate utilization. Negative for $\alpha$-galactosidase, $\beta$ galactosidase, $\beta$-phospho-6-galactosidase, $\alpha$-arabinosidase, $\alpha$-fucosidase, $\beta$-glucuronidase, alkaline phosphatase, arginine arylamidase, proline arylamidase, leucyl glycine arylamidase, phenylalanine arylamidase, leucine arylamidase, pyroglutamate arylamidase, tyrosine arylamidase, alanine arylamidase, glycine arylamidase, histidine arylamidase, glutamyl glutamate arylamidase, serine arylamidase, lysine decarboxylase, mannose fermentation, raffinose fermentation, indole formation and acetoin production. Positive for utilization of $\mathrm{N}$-acetylglucosamine, succinate, DL-malate, L-malate, $\alpha$-ketoglutarate, alanine, threonine, isoleucine, leucine, glycyl aspartate, glycyl glutamate, glycyl proline, alanyl glycine, gelatin, $\alpha$-ketobutyrate, monomethyl succinate, pyruvate, butyrate, caproate, $\beta$-hydroxypyruvate, $\alpha$-D-glucose, dextrin, D-galactose, maltose, $\alpha$-cyclodextrin, $\beta$-cyclodextrin, $\gamma$-cyclodextrin, maltotriose, adenosine, inosine, Tween 20, Tween 80, chondroitin sulfate, acetamide, putrescine and 2,3-butanediol; negative for utilization of acetate, propionate and Tween 40. Acid is produced from $\mathrm{N}$-acetyl-D-glucosamine. Acid is not produced from L-arabinose, D-xylose, D-adonitol, L-rhamnose, D-cellobiose, D-melibiose, sucrose, D-trehalose, D-raffinose or D-glucose. Fatty acids $\mathrm{C}_{\mathrm{i} 13: 0}(10 \%)$, iso- $\mathrm{C}_{13: 0} 3-\mathrm{OH}(6 \%)$, iso- $\mathrm{C}_{15: 0}$ $(36 \%), \mathrm{C}_{16: 0}(5 \%)$, iso- $\mathrm{C}_{17: 0}(3 \%), \mathrm{C}_{17: 1} \omega 8(13 \%)$ and $\mathrm{C}_{18: 1} \omega 7(3 \%)$ are present. Quinone composition is Q-7
(53\%), Q-8 (28\%) and MK-7 (74\%). The DNA G+C content is $53.8 \mathrm{~mol} \%$ (http://www.jgi.doe.gov) and the genome size is about $4.5 \mathrm{Mbp}$.

The type strain, PV $-4^{\mathrm{T}} \quad\left(=\mathrm{ATCC}\right.$ BAA $-1088^{\mathrm{T}}=\mathrm{DSM}$ $\left.17748^{\mathrm{T}}\right)$, was isolated from iron-rich microbial mats at the active, deep-sea, hydrothermal Naha Vent located on the South Rift of Loihi Seamount, Hawaii, in the Pacific Ocean.

\section{Acknowledgements}

We would like to thank Dr Joel A. Klappenbach for advice on DNADNA hybridization. This research was supported by the Department of Energy Office of Biological and Environmental Sciences under the 'Genomics: GTL Program' via the Shewanella Federation. Oak Ridge National Laboratory is managed by University of Tennessee-Battelle LLC for the Department of Energy under contract DE-AC0500OR22725.

\section{References}

Bowman, J., McCammon, S., Nichols, D., Skerratt, J., Rea, S., Nichols, P. \& McMeekin, T. (1997). Shewanella gelidimarina sp. nov. and Shewanella frigidimarina sp. nov., novel Antarctic species with the ability to produce eicosapentaenoic acid $(20: 5 \omega 3)$ and grow anaerobically by dissimilatory Fe(III) reduction. Int $J$ Syst Bacteriol 47, 1040-1047.

Bozal, N., Montes, M. J., Tudela, E., Jimenez, F. \& Guinea, J. (2002). Shewanella frigidimarina and Shewanella livingstonensis sp. nov. isolated from Antarctic coastal areas. Int J Syst Evol Microbiol 52, 195-205.

Brettar, I., Christen, R. \& Höfle, M. G. (2002). Shewanella denitrificans sp. nov., a vigorously denitrifying bacterium isolated from the oxicanoxic interface of the Gotland Deep in the central Baltic Sea. Int J Syst Evol Microbiol 52, 2211-2217.

Coyne, V. E., Pillidge, C. J., Sledjeski, D. D., Hori, H., Ortizconde, B. A., Muir, D. G., Weiner, R. M. \& Colwell, R. R. (1989). Reclassification of Alteromonas colwelliana to the genus Shewanella by DNA-DNA hybridization, serology and 5S ribosomal-RNA sequence data. Syst Appl Microbiol 12, 275-279.

Gauthier, G., Gauthier, M. \& Christen, R. (1995). Phylogenetic analysis of the genera Alteromonas, Shewanella, and Moritella using genes coding for small-subunit rRNA sequences and division of the genus Alteromonas into two genera, Alteromonas (emended) and Pseudoalteromonas gen. nov., and proposal of twelve new species combinations. Int J Syst Bacteriol 45, 755-761.

Goris, J., Suzuki, K., De Vos, P., Nakase, T. \& Kersters, K. (1998). Evaluation of a microplate DNA-DNA hybridization method compared with the initial renaturation method. Can J Microbiol 44, $1148-1153$.

Ivanova, E. P., Sawabe, T., Gorshkova, N. M., Svetashev, V. I., Mikhailov, V. V., Nicolau, D. V. \& Christen, R. (2001). Shewanella japonica sp. nov. Int J Syst Evol Microbiol 51, 1027-1033.

Ivanova, E. P., Sawabe, T., Hayashi, K., Gorshkova, N. M., Zhukova, N. V., Nedashkovskaya, O. I., Mikhailov, V. V., Nicolau, D. V. \& Christen, R. (2003a). Shewanella fidelis sp. nov., isolated from sediments and sea water. Int J Syst Evol Microbiol 53, 577-582.

Ivanova, E. P., Nedashkovskaya, O. I., Zhukova, N. V., Nicolau, D. V., Christen, R. \& Mikhailov, V. V. (2003b). Shewanella waksmanii sp. nov., isolated from a sipuncula (Phascolosoma japonicum). Int J Syst Evol Microbiol 53, 1471-1477. 
Ivanova, E. P., Gorshkova, N. M., Bowman, J. P., Lysenko, A. M., Zhukova, N. V., Sergeev, A. F., Mikhailov, V. V. \& Nicolau, D. V. (2004a). Shewanella pacifica sp. nov., a polyunsaturated fatty acidproducing bacterium isolated from sea water. Int $J$ Syst Evol Microbiol 54, 1083-1087.

Ivanova, E. P., Nedashkovskaya, O. I., Sawabe, T., Zhukova, N. V., Frolova, G. M., Nicolau, D. V., Mikhailov, V. V. \& Bowman, J. P. (2004b). Shewanella affinis sp. nov., isolated from marine invertebrates. Int J Syst Evol Microbiol 54, 1089-1093.

Ivanova, E. P., Flavier, S. \& Christen, R. (2004c). Phylogenetic relationships among marine Alteromonas-like proteobacteria: emended description of the family Alteromonadaceae and proposal of Pseudoalteromonadaceae fam. nov., Colwelliaceae fam. nov., Shewanellaceae fam. nov., Moritellaceae fam. nov., Ferrimonadaceae fam. nov., Idiomarinaceae fam. nov. and Psychromonadaceae fam. nov. Int J Syst Evol Microbiol 54, 1773-1788.

Kato, C., Li, L., Nogi, Y., Nakamura, Y., Tamaoka, J. \& Horikoshi, K. (1998). Extremely barophilic bacteria isolated from the Mariana Trench, Challenger Deep, at a depth of 11,000 meters. Appl Environ Microbiol 64, 1510-1513.

Kostka, J. E., Stucki, J. W., Nealson, K. H. \& Wu, J. (1996). Reduction of structural $\mathrm{Fe}(\mathrm{III})$ in smectite by a pure culture of Shewanella putrefaciens strain MR-1. Clays Clay Miner 44, 522-529.

Kumar, S., Tamura, K. \& Nei, M. (2004). MEGA3: integrated software for molecular evolutionary genetics analysis and sequence alignment. Brief Bioinform 5, 150-163.

Leonardo, M. R., Moser, D. P., Barbieri, E., Brantner, C. A., MacGregor, B. J., Paster, B. J., Stackebrandt, E. \& Nealson, K. H. (1999). Shewanella pealeana sp. nov., a member of the microbial community associated with the accessory nidamental gland of the squid Loligo pealei. Int J Syst Bacteriol 49, 1341-1351.

MacDonell, M. T. \& Colwell, R. R. (1985). Phylogeny of the Vibrionaceae, and recommendation for 2 new genera, Listonella and Shewanella. Syst Appl Microbiol 6, 171-182.

Makemson, J. C., Fulayfil, N. R., Landry, W., Van Ert, L. M., Wimpee, C. F., Widder, E. A. \& Case, J. F. (1997). Shewanella woodyi sp. nov., an exclusively respiratory luminous bacterium isolated from the Alboran Sea. Int J Syst Bacteriol 47, 1034-1039.

Myers, C. R. \& Nealson, K. H. (1988). Bacterial manganese reduction and growth with manganese oxide as the sole electron-acceptor. Science 240, 1319-1321.

Nogi, Y., Kato, C. \& Horikoshi, K. (1998). Taxonomic studies of deep-sea barophilic Shewanella strains and description of Shewanella violacea sp. nov. Arch Microbiol 170, 331-338.

Nozue, H., Hayashi, T., Hashimoto, Y., Ezaki, T., Hamasaki, K., Ohwada, K. \& Terawaki, Y. (1992). Isolation and characterization of Shewanella alga from human clinical specimens and emendation of the description of S. alga Simidu et al. 1990, 335. Int J Syst Bacteriol 42, 628-634.

Petrovskis, E. A., Vogel, T. M. \& Adriaens, P. (1994). Effects of electron acceptors and donors on transformation of tetrachloromethane by Shewanella putrefaciens MR-1. FEMS Microbiol Lett 121, 357-363.

Roh, Y., Gao, H., Vali, H. \& 9 other authors (2006). Metal reduction and iron biomineralization by a psychrotolerant $\mathrm{Fe}(\mathrm{III})$ reducing bacterium, Shewanella sp. PV-4. Appl Environ Microbiol 72, 3236-3244.

Russell, N. J. \& Nichols, D. S. (1999). Polyunsaturated fatty acids in marine bacteria - a dogma rewritten. Microbiology 145, 767-779.

Satomi, M., Oikawa, H. \& Yano, Y. (2003). Shewanella marinintestina sp. nov., Shewanella schlegeliana sp. nov. and Shewanella sairae sp. nov., novel eicosapentaenoic-acid-producing marine bacteria isolated from sea-animal intestines. Int J Syst Evol Microbiol 53, 491-499.

Satomi, M., Fonnesbech Vogel, B., Gram, L. \& Venkateswaran, K. (2006). Shewanella hafniensis sp. nov. and Shewanella morhuae sp. nov., isolated from marine fish of the Baltic Sea. Int J Syst Evol Microbiol 56, 243-249.

Semple, K. M. \& Westlake, D. W. S. (1987). Characterization of ironreducing Alteromonas putrefaciens strains from oil-field fluids. Can J Microbiol 33, 366-371.

Skerratt, J. H., Bowman, J. P. \& Nichols, P. D. (2002). Shewanella olleyana sp. nov., a marine species isolated from a temperate estuary which produces high levels of polyunsaturated fatty acids. Int J Syst Evol Microbiol 52, 2101-2106.

Smibert, R. M. \& Krieg, N. R. (1994). Phenotypic characterization. In Methods for General and Molecular Bacteriology, pp. 607-654. Edited by F. Gerhardt, R. G. E. Murray, W. A. Wood \& N. R. Krieg. Washington, DC: American Society for Microbiology.

Stackebrandt, E. \& Goebel, B. (1994). Taxonomic note: a place for DNA-DNA reassociation and 16S rRNA sequence analysis in the present species definition in bacteriology. Int J Syst Bacteriol 44, 846-849.

Stapleton, R. D., Jr, Sabree, Z. L., Palumbo, A. V., Moyer, C. L., Devol, A. H., Roh, Y. \& Zhou, J. (2005). Metal reduction at cold temperatures by Shewanella isolates from various marine environments. Aquat Microb Ecol 38, 81-91.

Toffin, L., Bidault, A., Pignet, P., Tindall, B. J., Slobodkin, A., Kato, C. \& Prieur, D. (2004). Shewanella profunda sp. nov., isolated from deep marine sediment of the Nankai Trough. Int J Syst Evol Microbiol 54, 1943-1949.

Venkateswaran, K., Dollhopf, M. E., Aller, R., Stackebrandt, E. \& Nealson, K. H. (1998). Shewanella amazonensis sp. nov., a novel metal-reducing facultative anaerobe from Amazonian shelf muds. Int J Syst Bacteriol 48, 965-972.

Venkateswaran, K., Moser, D. P., Dollhopf, M. E. \& 10 other authors (1999). Polyphasic taxonomy of the genus Shewanella and description of Shewanella oneidensis sp. nov. Int J Syst Bacteriol 49, 705-724.

Wayne, L. G., Brenner, D. J., Colwell, R. R. \& 9 other authors (1987). Report of the ad hoc committee on reconciliation of approaches to bacterial systematics. Int J Syst Bacteriol 37, 463-464.

Weiner, R. M., Coyne, V. E., Brayton, P., West, P. \& Raiken, S. F. (1988). Alteromonas colwelliana sp. nov., an isolate from oyster habitats. Int J Syst Bacteriol 38, 240-244.

Xu, M. Y., Guo, J., Cen, Y. H., Zhong, X. Y., Cao, W. \& Sun, G. P. (2005). Shewanella decolorationis sp. nov., a dye-decolorizing bacterium isolated from activated sludge of a waste-water treatment plant. Int J Syst Evol Microbiol 55, 363-368.

Yoon, J. H., Kang, K. H., Oh, T. K. \& Park, Y. H. (2004a). Shewanella gaetbuli sp. nov., a slight halophile isolated from a tidal flat in Korea. Int J Syst Evol Microbiol 54, 487-491.

Yoon, J. H., Yeo, S. H., Kim, I. G. \& Oh, T. K. (2004b). Shewanella marisflavi sp. nov. and Shewanella aquimarina sp. nov., slightly halophilic organisms isolated from sea water of the Yellow Sea in Korea. Int J Syst Evol Microbiol 54, 2347-2352.

Zhao, J. S., Greer, C. W., Thiboutot, S., Ampleman, G. \& Hawari, J. (2004). Biodegradation of the nitramine explosives hexahydro-1,3,5trinitro-1,3,5-triazine and octahydro-1,3,5,7-tetranitro-1,3,5,7-tetrazocine in cold marine sediment under anaerobic and oligotrophic conditions. Can J Microbiol 50, 91-96.

Zhao, J.-S., Manno, D., Beaulieu, C., Paquet, L. \& Hawari, J. (2005). Shewanella sediminis sp. nov., a novel $\mathrm{Na}^{+}$-requiring and 
hexahydro-1,3,5-trinitro-1,3,5-triazine-degrading bacterium from marine sediment. Int J Syst Evol Microbiol 55, 1511-1520.

Zhao, J.-S., Manno, D., Beaulieu, C., Paquet, L. \& Hawari, J. (2006). Shewanella halifaxensis sp. nov., a novel obligately respiratory and denitrifying psychrophile. Int J Syst Evol Microbiol 56, 205-212.
Zhou, J.-Z., Bruns, M. A. \& Tiedje, J. M. (1996). DNA recovery from soils of diverse composition. Appl Environ Microbiol 62, 316-322.

Ziemke, F., Hofle, M. G., Lalucat, J. \& Rossello-Mora, R. (1998). Reclassification of Shewanella putrefaciens Owen's genomic group II as Shewanella baltica sp. nov. Int J Syst Bacteriol 48, 179-186. 